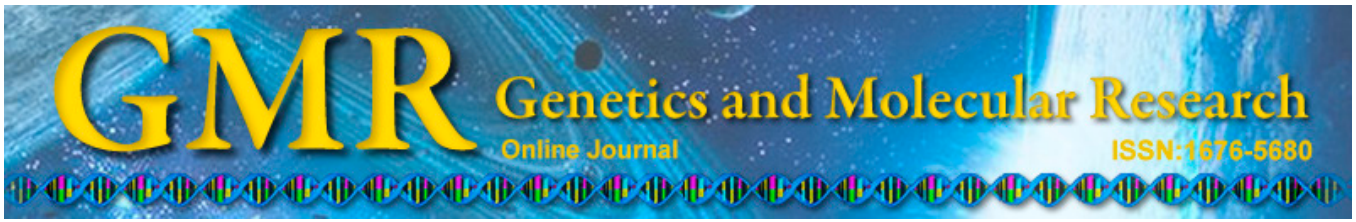

\title{
Novel SNPs in the growth arrest and DNA damage-inducible protein 45 alpha gene $(G A D D 45 A)$ associated with meat quality traits in Berkshire pigs
}

\author{
E.S. Cho*, K.T. Lee*, J.W. Choi, H.J. Jeon, S.W. Lee, Y.M. Cho and \\ T.H. Kim \\ Animal Genomics and Bioinformatics Division, \\ National Institute of Animal Science, \\ Rural Development Administration, Suwon, Korea \\ *These authors contributed equally to this study. \\ Corresponding author: T.H. Kim \\ E-mail: segi0486@korea.kr
}

Genet. Mol. Res. 14 (3): 8581-8588 (2015)

Received August 21, 2014

Accepted April 6, 2015

Published July 31, 2015

DOI http://dx.doi.org/10.4238/2015.July.31.6

\begin{abstract}
This study was conducted to evaluate the porcine gene GADD45A (growth arrest and DNA-damage-inducible protein 45 alpha) as a positional candidate controlling quantitative trait loci (QTL) for meat quality traits on chromosome 6 (SSC6). Four exons of the porcine GADD45A gene were defined from cDNA and BAC clone sequences. A total of 4 single nucleotide polymorphisms (SNPs) were identified in porcine GADD45A. The association of these SNPs (g.196A $>$ G, g.392C $>$ A, g.955T $>$ C and g.3247A $>$ T) with meat quality traits was evaluated in 678 Berkshire pigs. The genotype distribution of only one SNP (g.3247A>T) conformed to Hardy Weinberg equilibrium in the pig population analyzed in this study, and the other SNPs were not in Hardy-Weinberg equilibrium. All four SNPs were significantly associated with meat quality traits. Three SNPS (g.196A > G, g.392C > A,
\end{abstract}


and g.955T $>$ C) showed similar significant association patterns for drip loss, cooking loss, meat color (lightness; MC_L and yellowness; MC_B), shear force and water-holding capacity traits. By contrast, g.3247A $>$ T had a different association pattern with other traits such as intramuscular fat content (IMF) and backfat thickness (BF), drip loss, $\mathrm{MC} \_$L, and moisture. These findings will provide useful information for genetic characterization or association studies in other pig populations. Additionally, these markers can potentially be applied in pig breeding programs to improve meat quality traits, including IMF and BF.

Key words: Meat quality; Pig; Single nucleotide polymorphism; Growth arrest and DNA-damage-inducible protein 45 alpha gene

\section{INTRODUCTION}

Meat quality is one of the major factors influencing meat palatability. Consequently, the improvement of meat quality traits to meet rapidly growing consumer demand is one of the most important breeding targets in farm animals. Meat quality is determined by several factors, including intramuscular fat content (IMF), tenderness, water-holding capacity (WHC), and meat color (MC). Additionally, it is affected by many factors such as genetic effects, the production system, environmental conditions, handling before slaughter, and slaughter method (Rosenvold and Andersen, 2003). Meat quality traits are controlled by multiple genes on the chromosomal regions known as quantitative trait loci (QTL). Several QTLs for fat traits such as IMF (de Koning et al., 1999; Gerbens et al., 1999, 2000; Ovilo et al., 2000; Grindflek et al., 2001; Uleberg et al., 2005) and backfat thickness (BF) (Malek et al., 2001; Ovilo et al., 2002; Szyda et al., 2003; Soma et al., 2011) have been overlapped on pig chromosome 6 (SSC6). The leptin receptor (LEPR) and heart fatty acid-binding protein (h-FABP) genes are well-known potential candidates controlling QTLs for growth and fatness traits on SSC6 because of their positions and biological function. Polymorphisms in LEPR and $h-F A B P$ have been reported to be associated with IMF (Mackowski et al., 2005; Ovilo et al., 2005; Gerbens et al., 1997, 1999, 2000). Recently, the growth arrest and DNA-damage-inducible protein 45 alpha gene (GADD45A) was reported to be a potential candidate gene controlling QTL for BF and IMF traits (Lee et al., 2012). It was reported that GADD45A, which is located near $L E P R$, mapped to the pig chromosome 6q32 region, associated with a QTL for fat-deposit traits (Kim et al., 2006). GADD45A plays an essential role as a stress sensor that modulates the cellular response to various stress conditions, including genotoxic and oncogenic stresses (Fornace et al., 1992; Liebermann and Hoffman, 1998; Cretu et al., 2009). GADD45 is preferentially expressed in postmitotic adipocytes and transactivated by $C / E B P \alpha$ in a transient transfection assay (Constance et al., 1996). Recently, it was revealed that $G A D D 45 A$ protein plays a key role in gene-specific active DNA demethylation during the differentiation of adipose-derived mesenchymal stem cells (Zhang et al., 2011). Previously, we deposited the sequence of a BAC clone containing the porcine GADD45A gene into GenBank (accession No. FN673720, BAC clone KNP_175E3). This study was conducted to evaluate the pig GADD45A gene as a positional candidate gene controlling QTL for meat quality traits on SSC6. The structure of the GADD45A gene was defined on the basis of cDNA (Kim et al., 2006) and BAC clone sequences. Additionally, SNPs were discovered within the porcine GADD $45 A$ gene, including 
approximately $2 \mathrm{~kb}$ of the 5'-regulatory region. Moreover, an association study was conducted in a pure Berkshire population.

\section{MATERIAL AND METHODS}

The study protocol and standard operating procedures were reviewed and approved by the Institutional Animal Care and Use Committee of the National Institute of Animal Science (Suwon, Republic of Korea).

\section{Animals and trait measurement}

A total of 678 Berkshire pigs (331 castrated males and 347 females) were examined for the association study. These pigs were fed the same commercial feed at the same pig farm and slaughtered at an average body weight of $110 \mathrm{~kg}$. Slaughtering followed standard procedures under the supervision of a Korean grading service for animal products. After slaughter, the hot carcass weight was recorded, and BF was measured between the 10th and 11th ribs. Meat quality traits were evaluated according to the longissimus dorsi muscle. Nine items were measured as meat characteristics: meat $\mathrm{pH}$, WHC, drip loss, cooking loss, $\mathrm{MC}$, muscle shear force (SF), moisture, IMF, and crude protein. Meat $\mathrm{pH}$ was measured at $24 \mathrm{~h}$ after slaughter. The WHC of longissimus dorsi muscle immediately sampled after slaughter was determined using the filter-paper method described by Grau and Hamm $(1952,1956)$. Additionally, Drip loss during vacuum storage was determined at 1 day postmortem by weighing samples before and after storage. Cooking loss was measured as the difference between sample weights before and after incubation at $75^{\circ} \mathrm{C}$ for $10 \mathrm{~min}$. Meat color was measured using three coordinates from the Hunter L, a, b system, where L is a general indication of lightness, a represents the degree of green-redness, and $b$ represents the degree of blue-yellowness. SF was determined using a Warner-Bratzler shear force meter (G-R Electrical, USA). Moisture, IMF, and crude protein were analyzed according to standard methods of the American Organization of Analytical Chemists (Horowitz, 1980). The overall means and standard deviations of the 14 traits are shown in Table S1.

\section{SNP detection and genotyping}

Genomic DNA and total RNA were extracted fom longissimus dorsi tissues of Berkshire pigs using a Wizard Genomic DNA Purification kirt (Promega, Madison, WI, USA) and Trizol reagent (Invitrogen, USA) according to manufacturer instructions. The RNasefree DNAase kit (Qiagen Korea Ltd., Seoul, South Korea) was used to remove DNA contamination from total RNA. The DNase-treated total RNA was purified by using the RNeasy MinElute Cleanup kit (Qiagen Korea Ltd., Seoul, South Korea) according to manufacturer instructions. A $1-\mu \mathrm{L}$ aliquot of purified total RNA was mixed with $1 \mu \mathrm{L} 100 \mathrm{ng} / \mu \mathrm{L}$ random hexamers (Promega Korea Ltd., Seoul, South Korea), $4 \mu \mathrm{L} 2.5 \mathrm{mM}$ of each dNTP, and up to $13 \mu \mathrm{L}$ RNase-free $\mathrm{ddH}_{2} \mathrm{O}$, and the reaction mixture was incubated at $65^{\circ} \mathrm{C}$ for 5 min and quick chilled on ice for 3 min. Next, $4 \mu \mathrm{L} 5 \mathrm{X}$ First-Strand buffer, $1 \mu \mathrm{L} 0.1 \mathrm{M}$ DTT, $1 \mu \mathrm{L} 40 \mathrm{U} / \mu \mathrm{L}$ RNase inhibitor, and $1 \mu \mathrm{L} 200 \mathrm{U} / \mu \mathrm{L}$ SuperScript ${ }^{\mathrm{TM}}$ III RT (Invitrogen) were added, followed by incubation at $25^{\circ} \mathrm{C}$ for $5 \mathrm{~min}, 50^{\circ} \mathrm{C}$ for $60 \mathrm{~min}$ and then $70^{\circ} \mathrm{C}$ for $15 \mathrm{~min}$ in a thermal cycler (Verity 96-well thermal cycler; ABI). The primers were designed from the published cDNA 
sequences (accession No. DQ529285) and pig BAC clone KNP_175E3 to amplify the porcine GADD45A gene (Table 1). PCR was performed in $20-\mu \mathrm{L}$ volumes containing $10 \mathrm{pmol}$ of each primer, $0.25 \mathrm{mM}$ of each dNTP, $2 \mu \mathrm{L}$ 10X PCR buffer, 1.25 U DNA polymerase (Genet Bio, Chungnam, Korea), and 100 ng genomic DNA. The thermal cycling conditions included an initial 5-min denaturation at $94^{\circ} \mathrm{C}$ followed by 35 cycles of $30 \mathrm{~s}$ at $94^{\circ} \mathrm{C}, 30 \mathrm{~s}$ at $62^{\circ} \mathrm{C}$, and 1 min at $72^{\circ} \mathrm{C}$, with a final 10 -min extension at $72^{\circ} \mathrm{C}$ in a DNA Engine Tetrad ${ }^{\circledR} 2$ Thermal Cycler (Bio-Rad, Hercules, CA, USA). To detect nucleotide sequence variation, the PCR products were sequenced directly using a Big Dye Terminator Cycle Sequencing Ready Reaction kit V3.0 (Life Technologies, Carlsbad, CA, USA) and an ABI PRISM ${ }^{\circledR} 3730$ Genetic Analyzer $^{\circ}$ (Life Technologies). The sequences were compared to find SNPs using the program SeqMan (DNASTAR, Madison, WI, USA).

\begin{tabular}{|c|c|c|c|c|}
\hline Amplicon & Primer sequence $\left(5^{\prime} \rightarrow 3^{\prime}\right)$ & Template & Annealing temperature $\left({ }^{\circ} \mathrm{C}\right)$ & Size (bp) \\
\hline 1 & $\begin{array}{l}\text { Forward: TAGCTGGCTGATGACAGTGC } \\
\text { Reverse: CTTGCATCCGACAAAGATCA }\end{array}$ & gDNA & 60 & 864 \\
\hline 2 & $\begin{array}{l}\text { Forward: TTGCTGACAACGCAGTTAGG } \\
\text { Reverse: TTTCGGCAAAGCTGCTTATT }\end{array}$ & gDNA & 60 & 926 \\
\hline 3 & $\begin{array}{l}\text { Forward: CGCTTTGTGTGGAAAGGATT } \\
\text { Reverse: GCTCCCTCGTAGGCTACTCC }\end{array}$ & gDNA & 60 & 840 \\
\hline 4 & $\begin{array}{l}\text { Forward: GCTCCTCACAGCCTTGTTTC } \\
\text { Reverse: ACCCCTCCTACGTCCAGAGT }\end{array}$ & gDNA & 61 & 796 \\
\hline 5 & $\begin{array}{l}\text { Forward: ACGCCGCTCTCTCTCAGTAG } \\
\text { Reverse: CCATCACCGTTCAGGAAGAT }\end{array}$ & cDNA & 63 & 539 \\
\hline 6 & $\begin{array}{l}\text { Forward: TCAGTGGGTTTTGCATGTGT } \\
\text { Reverse: GTAGAGCAGGCCATCGGTAA }\end{array}$ & gDNA & 63 & 1173 \\
\hline
\end{tabular}

\section{Statistical analysis}

Association analysis was performed using SAS 9.13 (SAS Institute Inc., Cary, NC, USA). The following formula was used in a generalized linear model (GLM) analysis: $y_{i j k l}=$ $\mu+G_{i}+S_{j}+\mathrm{B}_{k}+P_{l}+e_{i j k l l}$, where $y_{i j k l}$ is the observed value, $\mu$ is the general mean, $G_{i}$ is the fixed effect of genotype $i, S_{j}$ is the fixed effect of $\operatorname{sex} j, B_{k}$ is the fixed effect of breed $k, P_{l}$ is the fixed effect of the period of slaughter $l$, and $e_{i j k l}$ is the random error. The results are reported as the least squares means for each group and standard errors (SEs) of the least squares means. Genotype, sex, breed were included as fixed effects in the statistical model. Differences were considered significant if $\mathrm{P}<0.01$ and $\mathrm{P}<0.05$.

\section{RESULTS AND DISCUSSION}

\section{Genomic organization of the porcine $G A D D 45 A$ gene}

Porcine GADD45A was previously mapped to SSC6q32, which corresponds to HSA1p13 (Kim et al., 2006). The genomic structure of the porcine GADD45A gene contained four exons $(333,102,238$, and $774 \mathrm{bp})$ and three introns, spanning approximately $3.4 \mathrm{~kb}$ of genomic DNA. The start condon for translation was located in exon 1 (Figure 1). The porcine GADD $45 A$ gene encodes a 165 -amino acid protein. A comparison of the deduced amino acid 
sequence of porcine $G A D D 45 A$ with those of other species revealed amino acid sequence identities of $98,98,92$, and $90 \%$ with cattle, human, mouse, and rat GADD45A, respectively (GenBank accession Nos. NP001029419.1, NP001915.1, NP031862.1, and NP077041.2). Furthermore, all exon/intron boundary sequences followed the GT-AG rule for splice-donor and acceptor sites reported by Jacob and Gallinaro (1989).

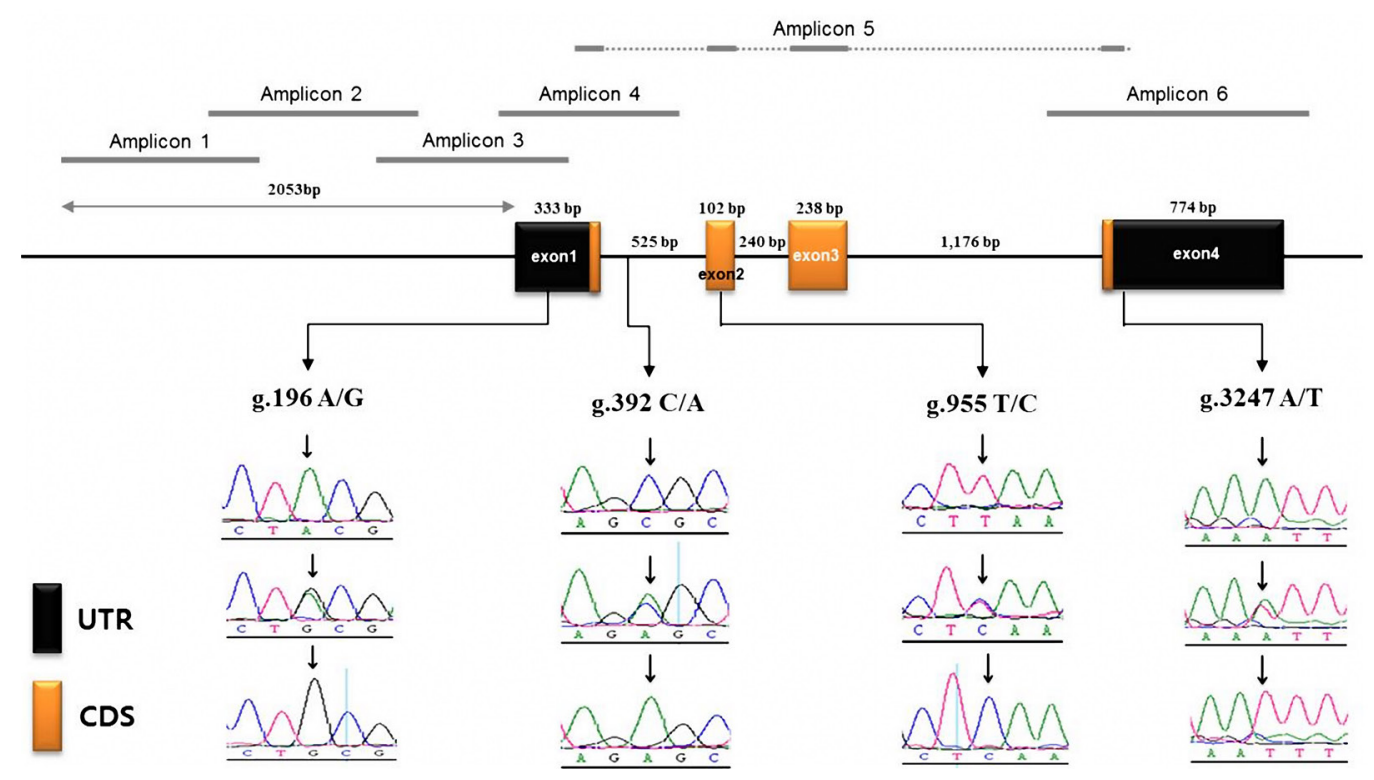

Figure. 1. Representative sequence chromatograms showing the polymorphisms identified in the GADD45A gene. The numbering refers to the sequence of GADDA45A (GenBank accession No. FN673720, Sus scrofa BAC clone KNP_175E3).

\section{SNP identification and association study}

Four polymorphic sites were found in the $5^{\prime}$ untranslated region (g.196A $\left.>\mathrm{G}\right)$, intron 1 (g.392C $>$ A), exon 2 (g.955T $>C$ ), and the $3^{\prime}$ untranslated region (g.3247A $>$ T) of the porcine GADD45A gene (Figure 1). Of the four polymorphic sites, g.955T $>$ C SNP was previously found (kps6413; Lee et al., 2012), and the other SNPs were newly identified in this study (g.196A $>$ G; ss974514574, g.392C $>$ A; ss974514575, g.3247A $>$ T; ss974514576). To estimate the genotypic and allelic frequencies for the four SNPs, 678 Berkshire pigs were genotyped and the results are given in Table 2. The genotype distribution of only one SNP (g. 3247A>T) conformed to Hardy Weinberg equilibrium in the pig population analyzed in this study, and the other SNPs were not in Hardy-Weinberg equilibrium. The four SNPs of porcine $G A D D 45 A$ were examined for association with meat quality traits of 678 Berkshire pigs (Table S1). As shown in Table S2 , three SNPs were significantly associated with meat quality traits. g.196 A $>$ G SNP and g.955T $>$ C SNP were significantly associated with traits for drip loss $(\mathrm{P}<0.01)$, cooking loss $(\mathrm{P}<0.01)$ and shear force $(\mathrm{P}<0.05)$. These results also suggest that the AA genotype of g.196 A $>$ G SNP and the TT genotype of g.955T $>$ C 
SNP were significantly associated with better meat quality. The g.392C $>$ A SNP was significantly associated with traits for WHC $(\mathrm{P}<0.01)$, drip loss $(\mathrm{P}<0.01)$, cooking loss $(\mathrm{P}<$ $0.01), M C \_L(P<0.01)$ and $M C \_b(P<0.05)$. These findings suggest that pigs with the $\mathrm{CC}$ genotype have better meat quality than those with other genotypes. In general, it is known that WHC is negatively correlated with drip loss and cooking loss. The genetic correlation between WHC and drip loss was very high (-0.9). Drip loss and cooking loss were positively correlated $(0.75 \pm 0.19)$ (Bidanel et al., 1994). Also as shown in Table 3, the g.3247A $>\mathrm{T}$ SNP affected different meat quality traits. Specifically, it had a highly significant effect on $\mathrm{BF}$ and IMF traits $(\mathrm{P}<0.01)$. It was also associated with drip loss, MC_L, and moisture traits $(\mathrm{P}<0.05)$. GADD45A was previously reported to be significantly associated with IMF and BF traits in a reference family crossed by Korean native pig and Landrace (Lee et al., 2012). Despite the different pig populations, this SNP had the same effect on IMF and $\mathrm{BF}$ traits. The $\mathrm{BF}$ and IMF traits are major factors affecting meat quality and important commercial selection criteria (Borchers et al., 1997; Gerbens et al., 2001). Therefore, we suggest that this SNP is a potential marker for IMF and BF traits. The GADD45A gene functions in growth arrest and terminates differentiation (Umek et al., 1991). The expression of $G A D D 45 A$ is induced by c/EBP $\alpha$, which is a key transcription factor related to adipocyte differentiation and has an anti-mitotic function that may cause growth arrest to terminate the clonal expansion phase of differentiation (Umek et al., 1991; Constance et al., 1996). However, it is not clear whether c/EBP $\alpha$ induces the expression of GADD45A directly. In pigs, the GADD45A gene is located on SSC6 (Kim et al., 2006). Previously, the porcine GADD45A was suggested to be a powerful marker of IMF and BF traits (Lee et al., 2012). However, the structural variation and regulatory functions of porcine $G A D D 45 A$ have not been examined. Two potential candidate genes (LEPR and $h$-FABP) are thought to be related to QTL for fat traits on SSC6 because of their locations and physiological functions. Highly significant genetic variants for fatness traits were detected in an experimental cross of Iberian and Landrace breeds, although it was difficult to determine whether those were casual SNPs because of linkage disequilibrium (Ovilo et al., 2002). Many research groups have found evidence for QTL related to fatness traits on SSC6, but no casual variant controlling QTL for fatness traits on SSC6 has yet been found. We found four SNPs of the GADD45A gene in a Berkshire pig population, one each in the 5'-untranslated region, intron 1, exon 2, and 3'-untranslated region. Three SNPs (g.196 A>G, g.392C $>$ A, and g.955T $>$ C) were very significantly associated with WHC, drip loss, cooking loss, meat color (MC_L, MC_B) and shear force. The fourth, g.3247A $>$ T SNP, had significant effects on IMF and BF, as reported by Lee et al. (2002). These findings provide information for genetic characterization or association studies in other populations. Additionally, these SNPs may be used as genetic markers to improve these meat quality traits in pigs.

Table 2. Allele and genotype frequencies of four GADD45A polymorphisms in Berkshire pigs.

\begin{tabular}{|c|c|c|c|c|c|}
\hline \multicolumn{2}{|l|}{ SNP position } & \multicolumn{2}{|c|}{ Genotype frequency $(\mathrm{N}=678)$} & \multicolumn{2}{|l|}{ Allele frequency } \\
\hline g.196 A>G & $\mathrm{AA}(596,0.88)$ & $\mathrm{AG}(76,0.11)$ & $\mathrm{GG}(6,0.01)$ & $\mathrm{A}(0.94)$ & $\mathrm{G}(0.06)$ \\
\hline g. $392 \mathrm{C}>\mathrm{A}$ & $\mathrm{CC}(624,0.92)$ & $\mathrm{CA}(53,0.07)$ & $\mathrm{AA}(1,0.01)$ & $\mathrm{C}(0.96)$ & $\mathrm{A}(0.04)$ \\
\hline g. $955 \mathrm{~T}>\mathrm{C}$ & TT $(595,0.88)$ & $\mathrm{TC}(76,0.11)$ & $\mathrm{CC}(7,0.01)$ & $\mathrm{T}(0.94)$ & $\mathrm{C}(0.06)$ \\
\hline g. $3247 \mathrm{~A}>\mathrm{T}$ & $\mathrm{AA}(117,0.17)$ & $\mathrm{AT}(352,0.52)$ & TT $(209,0.31)$ & $\mathrm{A}(0.43)$ & $\mathrm{T}(0.57)$ \\
\hline
\end{tabular}

The number of genotyped animals and genotype frequency are shown in parentheses. 
Table 3. Effects of g.3247 A $>\mathrm{T}$ in $3^{\prime}$ UTR region of GADD45A gene on meat quality traits.

\begin{tabular}{|c|c|c|c|c|c|}
\hline \multirow{2}{*}{$\begin{array}{l}\text { SNP } \\
\text { g.3247 A > T }\end{array}$} & \multirow[t]{2}{*}{ Traits } & \multicolumn{3}{|c|}{ Genotype means \pm standard errors (No. of individuals) } & \multirow[t]{2}{*}{ P value } \\
\hline & & $\mathrm{AA}(\mathrm{N}=117)$ & $\mathrm{AT}(\mathrm{N}=352)$ & TT $(\mathrm{N}=209)$ & \\
\hline & $\mathrm{BF}$ & $26.62 \pm 0.62^{1 a}$ & $25.50 \pm 0.49^{b}$ & $24.93 \pm 0.54^{\mathrm{b}}$ & $0.0013 * *$ \\
\hline & Drip loss & $5.12 \pm 0.22^{\mathrm{b}}$ & $4.94 \pm 0.17^{b}$ & $4.61 \pm 0.19^{\mathrm{a}}$ & $0.0274 *$ \\
\hline & MC_L & $49.40 \pm 0.35^{\mathrm{ab}}$ & $49.36 \pm 0.28^{\mathrm{a}}$ & $48.78 \pm 0.30^{\mathrm{b}}$ & $0.0391 *$ \\
\hline & Moisture & $75.50 \pm 0.12^{\mathrm{ab}}$ & $75.43 \pm 0.09^{\mathrm{a}}$ & $75.67 \pm 0.10^{\mathrm{b}}$ & $0.0183 *$ \\
\hline & IMF & $2.72 \pm 0.14^{\mathrm{a}}$ & $2.70 \pm 0.11^{\mathrm{a}}$ & $2.40 \pm 0.12^{b}$ & $0.0015 * *$ \\
\hline
\end{tabular}

$\mathrm{N}=$ number of pigs; $\mathrm{BF}=$ backfat thickness; $\mathrm{MC} \mathrm{L}=\mathrm{CIE}$ lightness; $\mathrm{IMF}=$ intramuscular fat content. ${ }^{1}$ Values are reported as least squares means and standard errors. ${ }^{\mathrm{a}, \mathrm{b}}$ Least square means with different superscripts in the same row differ. $* \mathrm{P}<0.05 ; * * \mathrm{P}<0.01$.

\section{ACKNOWLEDGMENTS}

Research supported by the National Institute of Animal Science (2-7-10 Agenda Research, \#PJ00670701), the Next-generation BioGreen "21" Program, Rural Development Administration, Republic of Korea (\#PJ008068), and the 2015 Post-doctoral Fellowship Program of the Rural Development Administration, Republic of Korea.

\section{Supplementary material}

\section{REFERENCES}

Bidanel JP, Ducos A, Labroue F, Guéblez B, et al. (1994). Genetic parameters of backfat thickness, age at $100 \mathrm{~kg}$ and meat quality traits in Piétrain pigs. Ann. Zootech. 43: 141-149.

Borchers T, Hohoff C, Buhlmann C and Spener F (1997). Heart-type fatty acid binding protein involvement in growth inhibition and differentiation. Prostaglandins Leukot Essent Fatty Acids 57: 77-84.

Constance CM, Morgan J and Umek RM (1996). C/EBP alpha regulation of the growth arrest-associated gene gadd45. Mol. Cell. Biol. 16: 3878-3883.

Cretu A, Sha X, Tront J, Hoffman B, et al. (2009). Stress sensor Gadd45 genes as therapeutic targets in cancer. Cancer Ther. 7: 268.

de Koning DJ, Janss LL, Rattink AP, van Oers PA, et al. (1999). Detection of quantitative trait loci for backfat thickness and intramuscular fat content in pigs (Sus scrofa). Genetics 152: 1679-1690.

Fornace AJ, Jackman J, Hollander MC, Hoffman-Liebermann B, et al. (1992). Genotoxic-stress-response genes and growth-arrest genes. Ann. N. Y. Acad. Sci. 663: 139-153.

Gerbens F, Rettenberge G, Lenstra JA, Veerkamp JH, et al. (1997). Characterization, chromosomal localization, and genetic variation of the porcine heart fatty acid-binding protein gene. Mamm. Genome 8: 328-332.

Gerbens F, Van Erp A, Harders F, Verburg F, et al. (1999). Effect of genetic variants of the heart fatty acid-binding protein gene on intramuscular fat and performance traits in pigs. J. Anim. Sci. 77: 846-852.

Gerbens F, De Koning D, Harders F, Meuwissen T, et al. (2000). The effect of adipocyte and heart fatty acid-binding protein genes on intramuscular fat and backfat content in Meishan crossbred pigs. J. Anim. Sci. 78: 552-559.

Gerbens F, Verburg F, Van Moerkerk H, Engel B, et al. (2001). Associations of heart and adipocyte fatty acid-binding protein gene expression with intramuscular fat content in pigs. J. Anim. Sci. 79: 347-354.

Grau R and Hamm R (1952). Eine einfache Methode zur Bestimmung der Wasserbindung in Fleisch. Fleischwirtschaft 4: 295-297.

Grau R and Hamm R (1956). Die Bestimmung der Wasserbindung des Fleisches mittels der Pressmethode. Fleischwirtschaft 8: 733-736.

Grindflek E, Szyda J, Liu Z and Lien S (2001). Detection of quantitative trait loci for meat quality in a commercial slaughter pig cross. Mamm. Genom. 12: 299-304.

Horowitz W (1980). Official methods of analysis of the Association of Official Analytical Chemists. AOAC, Washington, DC. 
Jacob M and Gallinaro H (1989). The 5' splice site: phylogetic evalution and variable geometry of association with U1RNA. Nucleic Acids Res. 17: 2159-2180.

Kim J, Lim H, Park E, Ovilo C, et al. (2006). A gene-based radiation hybrid map of the pig chromosome 6q32 region associated with a QTL for fat deposition traits. Anim. Genet. 37: 522-523.

Lee K, Byun M, Kang K, Hwang H, et al. (2012). Single nucleotide polymorphism association study for backfat and intramuscular fat content in the region between SW2098 and SW1881 on pig chromosome 6. J. Anim. Sci. 90: 1081-1087.

Liebermann DA and Hoffman B (1998). MyD genes in negative growth control. Oncogene 17: 3319-3329.

Mackowski M, Szymoniak K, Szydlowski M, Kamyczek M, et al. (2005) Missense mutations in exon 4 of the porcine LEPR gene encoding extracellular domain and their association with fatness traits. Anim. Genet. 36: 135-137.

Malek M, Dekkers JC, Lee HK, Baas TJ, et al. (2001). A molecular genome scan analysis to identify chromosomal regions influencing economic traits in the pig. II. Meat and muscle composition. Mamm. Genome 12: 637-645.

Ovilo C, Pérez-Enciso M, Barragán C, Clop A, et AL. (2000). A QTL for intramuscular fat and backfat thickness is located on porcine chromosome 6. Mamm. Genome 11: 344-346.

Ovilo C, Clop A, Noguera J, Oliver M, et al. (2002). Quantitative trait locus mapping for meat quality traits in an Iberian x Landrace F2 pig population. J. Anim. Sci. 80: 2801-2808.

Ovilo C, Fernández A, Noguera J, Barragán C, et al. (2005). Fine mapping of porcine chromosome 6 QTL and LEPR effects on body composition in multiple generations of an Iberian by Landrace intercross. Genet. Res. 85: 57-67.

Rosenvold K and Andersen HJ (2003). Factors of significance for pork quality a review. Meat Sci. 64: 219-237.

Soma Y, Uemoto Y, Sato S, Shibata T, et al. (2011). Genome-wide mapping and identification of new quantitative trait loci affecting meat production, meat quality, and carcass traits within a Duroc purebred population. J. Anim. Sci. 89: 601-608.

Szyda J, Grindflek E, Liu Z and Lien S (2003). Multivariate mixed inheritance models for QTL detection on porcine chromosome 6. Genet. Res. 81: 65-73.

Uleberg E, Widerøe I, Grindflek E, Szyda J, et al. (2005). Fine mapping of a QTL for intramuscular fat on porcine chromosome 6 using combined linkage and linkage disequilibrium mapping. J. Anim. Breed. Genet. 122: 1-6.

Umek RM, Friedman AD and McKnight SL (1991). CCAAT-enhancer binding protein: a component of a differentiation switch. Science 251: 288-292.

Zhang RP, Shao JZ and Xiang LX (2011). GADD45A protein plays an essential role in active DNA demethylation during terminal osteogenic differentiation of adipose-derived mesenchymal stem cells. J. Biol. Chem. 286: 41083-41094. 